\title{
ANÁLISIS MEDIANTE GEOMÁTICA DE TRES RETABLOS BARROCOS EN EL SURESTE ESPAÑOL: LA SINGULARIDAD DE UN PATRIMONIO RELIGIOSO DE INTERÉS TURÍSTICO ${ }^{1}$
}

\author{
Concepción Peña-Velasco* \\ Universidad de Murcia \\ https://orcid.org/0000-0002-6777-7258 \\ Josefina García-León** \\ Universidad Politécnica de Cartagena \\ https://orcid.org/0000-0001-7262-2245 \\ María de los Ángeles Riquelme Gómez*** \\ Universidad Politécnica de Cartagena \\ https://orcid.org/0000-0001-5724-5891
}

\begin{abstract}
RESUMEN
La documentación gráfica aportada por las nuevas tecnologías posee un enorme potencial para la investigación, docencia y difusión, que, en este caso, se ha aplicado a tres retablos del siglo XVIII, con categoría de BIC. Se ha realizado una modelización con Fotogrametría y Láser escáner. Los resultados, interpretados y debatidos por profesionales diversos, proporcionan información útil para el estudio del bien y permiten afrontar actuaciones de conservación y sensibilización patrimonial y plantear acciones destinadas a personas con discapacidad. Se hace un análisis comparativo y se reflexiona sobre la divulgación óptima como recurso turístico a partir de la documentación y análisis efectuados.
\end{abstract}

Palabras clave: retablo barroco español; fotogrametría; láser escáner; impresión 3D; divulgación patrimonial, recurso turístico.

Fecha de recepción: 21 de noviembre de 2020.

Fecha de aceptación: 10 de julio de 2021.

* Departamento de Historia del Arte. Universidad de Murcia. Campus de la Meced. 30001 MURCIA (España).E-mail: velasco@um.es

** Departamento de Arquitectura y Tecnología de la Edificación. Universidad Politécnica de Cartagena.

Edificio CIM. C/ Real, 3.30201 Cartagena (España).E-mail: josefina.leon@upct.es

*** E-mail: marianrik@gmail.com

1 Trabajo realizado dentro del Proyecto Hispanofilia IV, Cód. HaR2017-82791-C2-1-P financiado por: FEDER/Ministerio de Ciencia e Innovación - Agencia Estatal de Investigación. 


\title{
Geomatic Analysis of Three Baroque Altarpieces in Southeast Spain: The Singularity of a Religious Heritage Resource of Tourist Interest
}

\begin{abstract}
Graphic documentation provided by new technologies has enormous potential for research, teaching and dissemination. In this study, the technique is applied to three eighteenth-century altarpieces, officially recognized as Cultural Heritage Assets. A modelling was performed using photogrammetry and laser scanning. The results, interpreted and discussed by a range of professionals, provide useful information for studying the altarpieces and a basis for planning conservation, raising awareness and proposing actions aimed at groups with disabilities. The study includes a comparative analysis and considers ways of optimizing use as a tourist resource based on this type of documentation and analysis.
\end{abstract}

Keywords: Baroque Spanish altarpieces; photogrammetry; laser scanning; 3D printing; potential reach; touristic resource.

\section{SOBRE LA FUNCIÓN Y USO DE EL RETABLO BARROCO Y SU IMAGEN FOTOGRAMÉTICA}

El estudio métrico con diferentes metodologías de los retablos barrocos españoles permite reflexionar sobre las posibilidades de análisis de estos bienes patrimoniales, que poseen un importante potencial turístico. En su mayoría son de madera dorada y muchos han sufrido alteraciones. Un número considerable ha desaparecido, sin que apenas haya perdurado documentación gráfica. Solo en contados casos persisten las trazas que sirvieron de modelo para su realización. Además, fotografías anteriores a su destrucción - generalmente en conflictos bélicos-, estampas y pinturas muestran cómo eran y completan la información sobre su tipología y sobre los elementos que los conformaron, descritos, a veces, en escrituras de encargo, cartas de pago y pleitos, así como en testimonios literarios de diferente carácter. En ocasiones, a partir de este material se han efectuado recreaciones-ideales y más o menos certeras- y reconstrucciones - antaño dibujadas y ahora virtuales - , así como restituciones parciales.

La mayoría de los retablos históricos españoles poseen algún grado de protección legal. Muchos permanecen in situ y, en consecuencia, cumplen su función de amparar la imagen sacra, vestir el templo y erigirse en un marco escenográfico, que adquiere su magnificencia durante la liturgia. Precisamente es en el ritual cuando estas arquitecturas lígneas despliegan y exhiben sus valores como patrimonio material e inmaterial, en un ambiente pródigo para estimular los sentidos. Numerosos son los factores que contribuyen a despertar sensaciones: el olor a incienso y flores; los aspectos sonoros; la iluminación cambiante según la hora del día y el número de velas encendidas²; las tornadizas impresiones cromáticas suscitadas al contemplar la mazonería, las imágenes devocionales, los

2 Dependía de que fuera una celebración ordinaria, una fiesta o una solemnidad y de que oficiara el obispo. Todavía hoy, aunque no se especifica, hay quien respeta la tradición. 
colores de los ornamentos sacerdotales y del adorno del altar, los objetos de plata y cuantos elementos suntuarios exornan y enriquecen la capilla durante el ceremonial.

El entendimiento y disfrute del bien adquiere su razón de ser en el ámbito para el que fue diseñado y durante el rito. La tecnología no es capaz de trasladar a la imagen o a la copia exacta del objeto que se genere toda la dimensión de los aspectos performativos y sensibles. El retablo barroco constituye un marco grandilocuente y un sitial para las imágenes devocionales, que en el pasado se valió de tramoyas y recursos teatrales (Rodríguez G., 1992). Se puede articular un entorno de realidad virtual -redundando en este caso más aún en el antagonismo de las palabras del oxímoron-, o bien dotar de mutabilidad a la imagen digital que el retablo proporciona con el movimiento de bocaportes y puertas que ocultan o permiten la visión de camarines y tabernáculos o con modificación lumínica y de sombras. Cabe incorporar a la imagen generada el ajuar eucarístico y lo sonoro con voz y con música litúrgica e, incluso, procesional, cuando corresponda. Sin embargo y pese a la importancia que poseen las nuevas tecnologías aplicadas a las Humanidades, la visión que proporciona el facsímil no sustituye a la del objeto artístico y más cuando se encuentra en el espacio para el que fue creado, interaccionado con él y evocando la conexión con la sociedad para la que se concibió. No es factible recrear lo que implica la contemplación en el lugar y durante las celebraciones religiosas, con toda la multisensorialidad que conlleva y las emociones que despierta. El simulacro del objeto, no es el objeto, ni puede competir con él, ni con su puesta en escena. Sin embargo, son muchas e importantes las posibilidades que ofrecen las imágenes digitales para la investigación, estudio y acercamiento al público y, en particular, a personas vulnerables. Recientemente, se han instalado en su ubicación original reproducciones exactas de obras maestras de pintura y escultura, copiadas merced a las posibilidades que ofrecen las nuevas tecnologías, tomando los datos de las piezas originales que están en los museos y otros lugares y se ha reflexionado sobre lo que aportan tales reproducciones y qué papel tienen (Lowe et al., 2020)ํ․ Además, se está utilizando el facsímil como sustituto del original en exposiciones temporales, evitando los riesgos del traslado de la obra y en aras a su preservación.

El objetivo de este trabajo es realizar, estudiar y poner al servicio de la sociedad la documentación gráfica de tres retablos barrocos de diferentes localidades españolas por métodos complementarios, como son la fotogrametría digital convergente y la medición con escáner láser, apoyadas en la topografía clásica. Obtenido el modelo tridimensional de los retablos, se trata de llevar a cabo un análisis de las obras y, al propio tiempo, divulgarlas a través de la web con acceso libre, programar exposiciones y efectuar réplicas parciales con impresoras $3 \mathrm{D}$, que procuren un conocimiento inclusivo, permitiendo que personas con discapacidad visual accedan y disfruten, a través del tacto, de estas piezas artísticas.

3 La exposición La Ricoperta di un Capalavoro, inaugurada en 2020 y que está teniendo como marco el Palazzo Fava de Bolonia, incluye una parte, comisariada por Adam Lowe y Guendalina Damone, dedicada a las posibilidades de las nuevas tecnologías ante el objeto artístico y al entendimiento de las imágenes generadas como médium que se posiciona entre la materialidad de la pieza y su aura. Incluye propuestas de cómo podrían haber sido retablos desaparecidos, pero de los que se conservan los cuadros que los integraban https://www. factumfoundation.org/pag/1598/the-materiality-of-the-aura-new-technologies-for-preservation [Consulta 5 de noviembre de 2020]. 
Se han escogido tres retablos barrocos españoles que forman parte de dos templos y una capilla declarados Bien de Interés Cultural. En consecuencia y según la Ley 16/1985, de 25 de junio, del Patrimonio Histórico Español, incluyen los bienes y elementos contenidos y consustanciales al monumento y a su historia, como son las obras analizadas. En el primer caso, se encuentran los retablos mayores de San Miguel en Murcia y de Santa Catalina en El Bonillo en Albacete. En el segundo, está la llamada capilla marraja de Nuestro Padre Jesús Nazareno de Santo Domingo en Cartagena, perteneciente a una cofradía histórica y con presencia esencial en las procesiones de Semana Santa, declaradas de Interés Turístico Internacional.

La aplicación de las nuevas tecnologías a los retablos, con todo lo que conlleva de nuevas posibilidades de análisis a partir de las bases tradicionales de estudio en cuanto a la forma y técnica (Martín González, 1993; González-Alonso, 1997), llega con retraso respecto a su empleo en otras obras de arte, especialmente de escultura y arquitectura (Melendreras et al., 2020; Romero, 2020; Torner et al., 2019), así como de apoyo a la arqueología y museos (Gaiani et al., 2011, 2020) 4 . Si bien, se está avanzando en este campo y se ha efectuado restitución fotogramétrica de retablos a partir de otros similares conservados y de la descripción de los desaparecidos, considerando el espacio arquitectónico que los acogía (Dávila, 2014). Además, esta y otras técnicas han sido muy útiles en trabajos de restauración (Cantos et al., 2009; Ceballos, 2017). Sin embargo, queda mucho por hacer y deliberar a partir de los resultados obtenidos. La Geomática tiene un papel esencial en la investigación de los retablos, en la divulgación patrimonial, en la planificación turística, en las enseñanzas a diferentes niveles y en el acercamiento de la obra de arte a colectivos con discapacidad y a personas con cualquier dificultad para visitarlos. Además, se acude a las imágenes generadas y a la información que contienen por deleite, distracción o para satisfacer la curiosidad. En otro sentido, el material obtenido cabe utilizarlo como recurso didáctico en videojuegos, cada vez más explotados en el ámbito de las Humanidades Digitales y, en particular, de la Historia (Jiménez Alcaraz et al. (coord.), 2020). En los retablos, cabe arbitrar opciones de juegos interactivos que propicien la familiarización con términos arquitectónicos y con actividades centradas en tipologías, en aspectos relacionados con la iconografía y en otros susceptibles de ser planteados.

Los retablos del barroco español, y en concreto los retablos mayores que son los más relevantes, suelen conservarse en los templos para los que fueron concebidos, con lo que implica de diálogo con el espacio que los cobija. Generalmente, cuando se trasladaron a otros lugares fue con motivo de la expulsión de los jesuitas en el siglo XVIII, de las desamortizaciones decimonónicas y de conflictos bélicos, pero también por otras razones, como lo que está aconteciendo actualmente en comunidades religiosas, que están dejando el cenobio que habitaron durante siglos, con el riesgo que puede experimentar el patrimonio y los problemas originados al llevarse los bienes muebles o, en el caso de los retablos, las imágenes devocionales que acogen. Hay retablos que están en museos y existe algún museo de retablos. Ciertos templos se han musealizado o se han readaptado como salas de

4 Un proyecto reciente liderado por Victoria Soto Caba aborda el estudio la fiesta barroca y las reconstrucciones virtuales de lo efímero. Información sobre el mismo disponible en https://festdigital.hypotheses.org [Consulta 5 de noviembre de 2020]. 
exposiciones y para otros usos, habitualmente institucionales, y estos muebles litúrgicos unas veces se muestran y otras están tapados. Los retablos reunidos en ámbitos museísticos suelen ser los de menor tamaño, mayor antigüedad o bien se trata de obras que formaron parte de ciclos pictóricos y escultóricos de altares, pero que se desmontaron, dispersaron e independizaron del marco que los acogía.

Los templos no son museos, con sus horarios establecidos de visitas. En consecuencia, hay que acomodarse a las exigencias del culto y a las horas de apertura de la iglesia para poder contemplarlos. La mayor parte de los retablos mayores barrocos en España ostentan un elevado grado de protección legal. Muchos son Bien de Interés Cultural; es decir, poseen la máxima categorización legal. Ello implica el obligado establecimiento de cuatro días al mes de apertura al público, que afecta tanto a bienes inmuebles de titularidad pública como privada (Gallego, 2017), pero también exige el respeto a los derechos de los propietarios; en este caso y salvo casos excepcionales, la Iglesia Católica. Por otro lado, junto a la Ley 16/1985, de 25 de junio, del Patrimonio Histórico Español y a las leyes de patrimonio de las diferentes comunidades autónomas españolas que los amparan, también los retablos forman parte de bienes asociados a ritos que están protegidos por la Ley 10/2015, de 26 de mayo, para la salvaguardia del Patrimonio Cultural Inmaterial. En consecuencia, poner el mundo de lo digital al servicio del conocimiento, conservación y difusión del retablo es importante. Así, el público al que llegue la información será más amplio que el académico-al que van destinados los estudios especializados sobre estos bienes - o el que contempla el bien porque acude al templo por razones devocionales, pero no suele conocerlo en profundidad en sus aspectos artísticos. A partir del material obtenido mediante técnicas geomáticas, se podrían, además, organizar actividades y generar fórmulas para impulsar el interés por un patrimonio tan destacado como este.

\section{LOS RETABLOS OBJETO DE ESTUDIO}

La elección de las obras a estudiar y la formación de un equipo de trabajo con expertos en Geomática y en retablos sentaron las bases para comenzar este proyecto. Se eligieron tres piezas relevantes de madera, de cronología similar y con el máximo nivel de protección, con lo que implica de exigencia legal de mayor tutela. Las obras seleccionadas datan del segundo tercio del siglo XVIII. Una está en Murcia, capital del antiguo reino del mismo nombre. Se ubica en el altar mayor de una de las parroquias más antiguas de la ciudad, cuyo templo fue reconstruido a finales del siglo XVII y concluido a comienzos de la centuria siguiente. En consecuencia, la arquitectura del templo y del retablo guardan unidad estilística. Igual sucede con el que se sitúa en Cartagena, ciudad portuaria importante y, desde 1726, sede del Departamento Marítimo del Mediterráneo. Se trata de la primera capilla de la nave de la epístola de la Iglesia de Santo Domingo, originariamente perteneciente a esta orden y hoy iglesia castrense de cronología posterior. Estas dos localidades del Sureste peninsular español pertenecen a la Región del Murcia y a la Diócesis de Cartagena. El Bonillo está más al interior, en la provincia de Albacete y comunidad autónoma de Castilla-La Mancha. Formaba parte de la Diócesis de Toledo hasta que se creó la Diócesis de Albacete, a mediados del siglo XX. La iglesia del XVI, siglo en 
que la localidad obtuvo el villazgo, se amplió y experimentó importantes alteraciones y remodelaciones en las primeras décadas del XVIII, culminando con el encargo del retablo (Herrera y Zapata, 2002).

Tipológicamente, los retablos mayores mencionados de San Miguel y Santa Catalina obedecen al modelo imperante de cuerpo único con orden gigante que delimita tres calles -con la central de mayor entidad- y ático que ocupa la totalidad del testero del presbiterio. La secuencialidad de los ciclos pictóricos ya no tiene cabida en estos retablos que solo albergan escultura y presentan voluminosa decoración. Las imágenes originales de la obra de El Bonillo, salvo los cuatro ángeles del ático, no se han conservado, habiendo sido sustituidas por otras posteriormente. En cambio, las de la parroquia murciana conforman un ciclo iconográfico con los siete arcángeles y la Fe. San Miguel fue encargada en 1708 al artista napolitano Nicolás Salzillo. Las demás son obra temprana de Francisco Salzillo, uno de los más importantes escultores españoles del Setecientos. Se contrataron al unísono que el retablo, concertado ante notario en 1731, cuando se había fabricado el primer tercio (Sánchez Moreno, 1945: 90-91).

El ejemplar murciano marca un punto de inflexión en la historia del retablo en la antigua Diócesis de Cartagena al imponer una planta cóncava con adelantamiento de la calle central, potente movimiento y quiebro de estructuras. Sirvió de modelo a otros. Abandona la columna salomónica, fuertemente arraigada en las primeras décadas del siglo XVIII. La traza y factura se deben a Jacinto Perales, tallista que trabajó en localidades de la Gobernación de Orihuela y en el Reino de Murcia. El tipo de acabado de la obra con color, acometido en 1742, estaba abocado a su fin, pues se imponía el dorado completo de la estructura arquitectónica. Sucede en los retablos colaterales y del crucero, que conforman un conjunto significativo en la cabecera de este templo. El proyecto de la policromía, que no su ejecución, se debe a Francisco Salzillo. El color posee connotaciones simbólicas y se relaciona con la gama cromática de la escultura del titular. El derrumbamiento de la torre de la iglesia en 1864 causó numerosos daños al retablo, que fue alterado en elementos de ornamentación y otros (Peña-Velasco et al., 2017).

Respecto al retablo de El Bonillo, en 1733 Juan de Mata, escultor procedente de Villanueva de la Jara en el obispado de Cuenca, suscribió escritura de obligación para realizarlo en tres años (García-Saúco, 2002). Tipológicamente se articula con cuatro columnas salomónicas, iguales dos a dos en el ornamento de sus espiras, en la disposición de las cabezas de los angelitos que incorporan y en el giro de sus fustes de fuera a adentro. Estos soportes conviven con fragmentados estípites, que se disponen flanqueando las hornacinas y en el ático. La obra experimentó estragos en la Guerra de España y presenta modificaciones en la estructura y no conserva el tabernáculo.

En cuanto a la Hermandad de Nuestro Padre Jesús Nazareno de Cartagena, se hizo un primer retablo para adorno de la nueva capilla, que estaba erigido en 1731. En 1748 Nicolás Tomás, tallista, contrató un camarín como sitial para acoger la imagen del Nazareno, que suscitaba gran devoción y salía en procesión en Semana Santa y también en rogativa por lluvia (Montojo y Mestre, 2009). Fue dorado en 1752. En las décadas siguientes se amplió y ocupó todo el muro. El ático alberga cuadros de la Crucifixión, el Calvario y el Descendimiento entre rocallas donde descansan dos ángeles barrocos sosteniendo atributos. Varias imágenes se destruyeron en la Guerra de España. Antes y 
después de tan trágica contienda, la Cofradía Marraja, profundamente enraizada en el sentir popular cartagenero, encargó a acreditados escultores sus imágenes devocionales. Ha procurado mantener las cinco emplazadas en el retablo y la reposición de la Verónica aconteció en diciembre de 2019.

\section{MÉTODOS}

La toma de datos es esencial y el trabajo de campo debe ser riguroso para luego disponer de datos fiables. Los métodos a utilizar son respetuosos con la obra y, de modo complementario, permiten resolver las formas intrincadas del Barroco y el color monocromo de ellas, con ese recubrimiento de pan de oro, que les imprime un color dorado característico. Se ha utilizado de modo complementario la fotogrametría convergente terrestre, la medición de láser escáner y la topografía clásica para la documentación del patrimonio (Remondino, 2011; Yastikli, 2007), en este caso de retablos barrocos.

\subsection{Toma de datos}

Se realizó durante varios años. En el caso del retablo mayor de San Miguel en Murcia, se hizo entre 2016. En junio de 2017 se tomaron los datos en el retablo barroco de la Iglesia de Santo Domingo en Cartagena. En la iglesia parroquial de Santa Catalina en El Bonillo de Albacete, la toma fotográfica y el láser escáner tuvo lugar en diciembre de 2019. Para la captura de las imágenes se retiraron todos los elementos externos que autorizaron los propietarios, así como las luminarias que en ese momento estaban colocadas en ellos y que se pudieron apagar. Además fue necesario quitar la iluminación directa existente en los laterales de la iglesia y que enfocan directamente hacia cada uno de los retablos. Contar con una iluminación indirecta apropiada es fundamental, principalmente para los datos fotogramétricos, ya que unas imágenes nítidas y con buen contraste permiten la obtención de un modelo más preciso (Cipriani et al., 2015).

Para la obtención de datos a través de escaneado láser, se utilizó la multiestación Leica Geosystems MS50 1" R2000, tratándose esta de un escáner láser y estación total (Fig. 1). Este instrumento combina ambas tecnologías, el rigor de una estación total y un escáner 3D de precisión con imágenes digitales. Se utilizaron varios puntos de estación enlazados mediante topografía clásica y se tomaron al mismo tiempo las coordenadas de puntos de apoyo y control, tanto preseñalizados, como puntos naturales de los retablos.

La red poligonal desde donde se tomaron los datos del escáner láser es similar en los tres casos de estudio. Se establece un sistema local, con el que se enlazan los puntos de la poligonal, desde los cuales se realiza la medición de las diferentes nubes de puntos, que, al estar orientadas en el mismo sistema, aparecen encajadas todas en las nubes de puntos. Los puntos suelen establecerse desde diferentes alturas, utilizando estaciones en el coro elevado, si lo hay o a través de plataformas temporales puestas para la toma de datos, que permiten obtener datos de las partes más elevadas y tras las cornisas, que suelen ser los puntos más complicados, para poder luego completar el modelo fotogramétrico. 
Figura 1

ESTACIONES, PUNTOS DE APOYO Y CONTROL Y NUBE DE PUNTOS DE LA PARTE ARQUITECTÓNICA DEL RETABLO DE LA IGLESIA DE SANTO DOMINGO EN CARTAGENA Y DE LA ESCULTURA DE NUESTRO JESÚS EL NAZARENO, TITULAR DE DICHO RETABLO

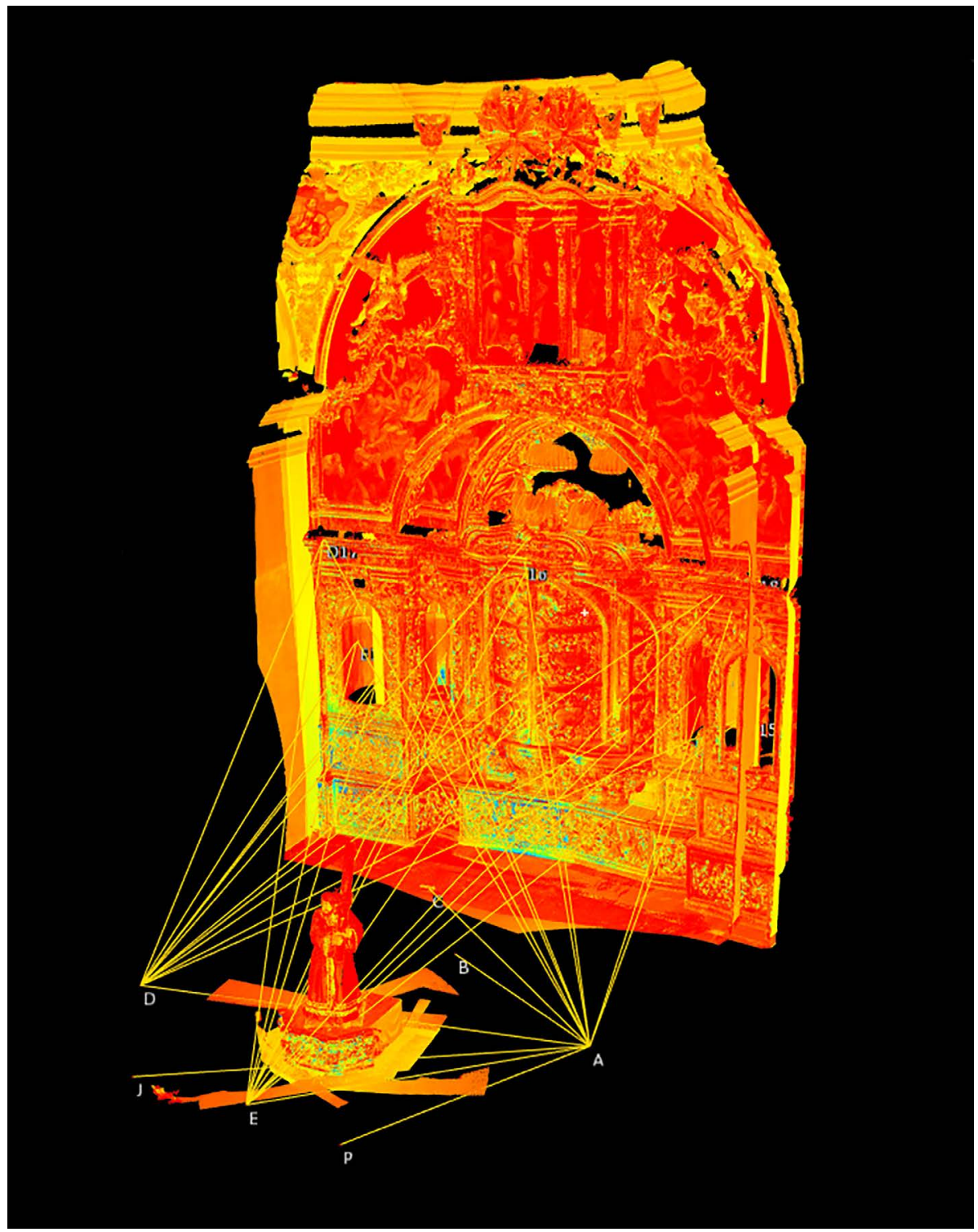

Fuente: Elaboración propia. 
Para la toma de datos fotogramétrica se han utilizado cámaras réflex no métricas, la Canon EOS 700D (Fig. 2.a) y la 1100D, con un sensor CMOS de 18 megapíxeles con velocidad de obturación 1/15, y un objetivo Canon ajustado a una distancia focal de 16-1721 y $22 \mathrm{~mm}$ según el posicionamiento hacia el retablo y, en el segundo caso, una focal de 18 a $55 \mathrm{~mm}$. La extracción de datos se hizo mediante formato RAW para lograr una mayor información de las imágenes en su posterior procesado (Fig. 2.b). Anteriormente a la toma de imágenes se realizó la previa colocación de dianas preseñalizadas (Fig. 2.d), impresas en pegatinas (Fig. 2.c) y ubicadas en diferentes puntos del retablo, a diferentes distancias, que fueron utilizadas para llevar a cabo la orientación absoluta del modelo tridimensional y el control del error.

\section{Figura 2 \\ A) CÁMARA FOTOGRÁFICA CANON EOS 700D; B) CARTA DE COLOR; C) MARCADORES DE DIANA D) EJEMPLO DE COLOCACIÓN DE LA PRESEÑALIZACIÓN EN EL RETABLO DE SANTA CATALINA (EL BONILLO)}
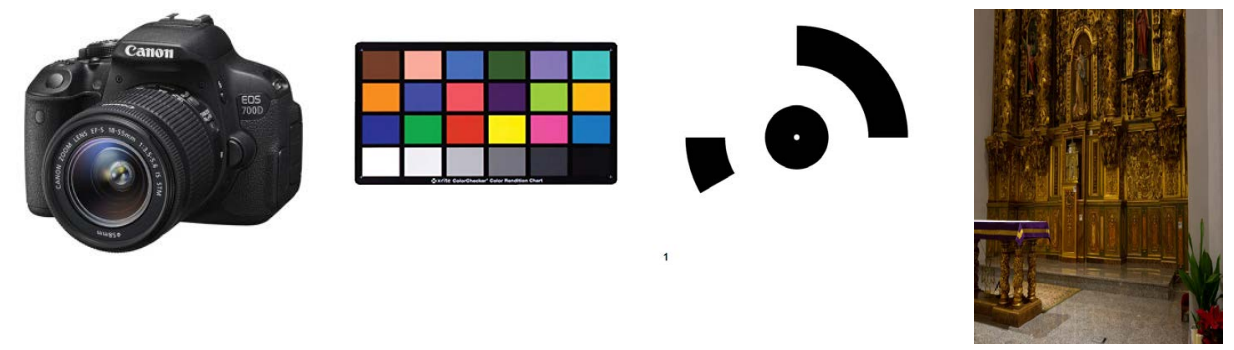

Fuente: Elaboración propia.

La metodología de trabajo se realizó mediante series de fotografías a diferentes distancias (que ocasionó los cambios de objetivo) y ángulos; es decir, debido a la gran dimensión del retablo y a la dificultad de llegar a dicha altura, las fotografías se planificaron para alcanzar los elementos más complicados. La variación no fue solo en distancia hacia el objeto, también se necesitó cambiar las alturas en las que se realizaban las imágenes (series o anillos), como puede verse en la figura 3, tanto en la toma cenital como en la vista lateral. Es fundamental que entre las imágenes haya el suficiente solape, tanto vertical como horizontal, para, posteriormente, obtener la orientación y el modelo. Para este proceso fue necesario la utilización de una pértiga, Elinchrom Tripod Air HD 124-385 $\mathrm{cm}$, para alcanzar la mayor altura posible. Se tomaron imágenes en un total de 3 anillos a diferentes alturas: 1.60, 2.95 y 3.85 metros (Fig. 3.b). La distancia entre las fotografías se realizó de la manera más homogénea posible. En total en el retablo mayor de la Iglesia de Santa Catalina se tomaron un número de 239 fotografías del modelo, con una resolución de 5184 x 3456, divididas en cuatro series según su distancia focal. En el retablo de la Iglesia de Santo Domingo se utilizaron 156 imágenes para el retablo y una media de 100 imágenes para cada escultura. 
El trabajo de toma de fotografías se efectuó con una previa planificación de las vistas necesarias. Se realizó una primera secuencia de fotos a 1.60 metros de altura posicionando la cámara de forma perpendicular al objeto y generando un solape entre imágenes para evitar el ruido posible por los efectos que la luz pueda incidir en el retablo. Generada esta primera secuencia, se elevó la altura del trípode y se realizó el mismo proceso a una altura de 2.95 metros y así una tercera vez a la mayor altura posible de la pértiga, 3.85 metros. Además, en esta última vuelta se realizaron imágenes con ángulo hacia la parte superior para poder captar todos los detalles de los elementos sobresalientes y, de la misma forma, hacia la parte inferior.

\section{Figura 3}

POSICIONAMIENTO DE LAS IMÁGENES EN RELACIÓN CON EL RETABLO MAYOR DE SANTA CATALINA (EL BONILLO) A) VISTA CENITAL DE LA TOMA DE IMÁGENES; B) VISTA LATERAL

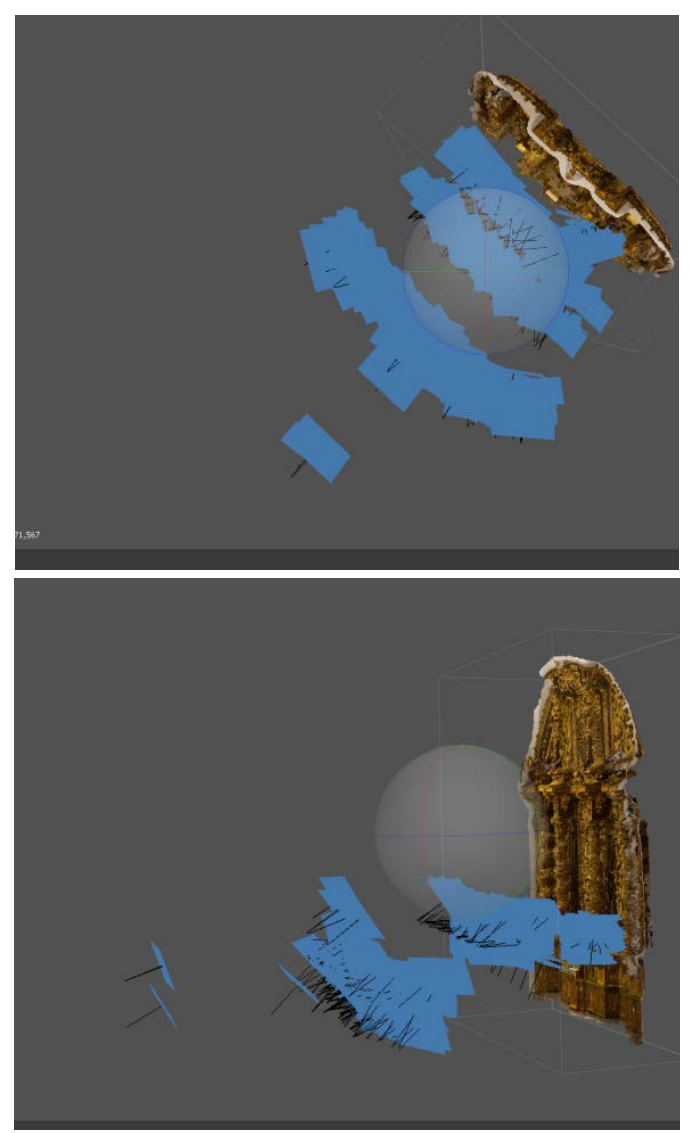

Fuente: Elaboración propia. 


\subsection{Procesado de datos}

Finalizada la fase de toma de datos se procede al volcado de la información obtenida. La posibilidad de tomar datos a través de varias técnicas diferentes ayuda no sólo a contrastar la información, sino también a complementar lo obtenido, generando así unos resultados de mayor precisión del retablo. En cuanto a los datos tomados con el láser escáner, se ha procedido al volcado utilizando el programa Infinity, para poder exportarlos en formatos aptos para su procesado en otros programas.

Los datos fotogramétricos se almacenen en formato raw, lo cual permite ser corregidas de iluminación y el color a un formato manejable como es el dng. Para la corrección de la iluminación de las imágenes, el correspondiente a la carta de color utilizada (Fig. 2.b), se han utilizado los programas Color Checker Passport y el Lightroom 5.7. Este procedimiento admite corregir los blancos de las imágenes para conseguir aumentar la exactitud de los detalles. Tras la imágenes corregidas se utilizó el programa de fotogrametría PhotoScan Agisoft, para generar una nube de puntos densa de alta calidad. Esta permite controlar mejor la creación del modelo y eliminar fallos de una forma sencilla. Esta fase, debido a la cantidad de puntos de enlace, dio la oportunidad de obtener una calibración inicial de la cámara y la lente utilizada. Se trata de un proceso semiautomático que proporciona unos parámetros adicionales a las imágenes, que serán los que posteriormente utilice el programa para orientar las fotografías.

\subsection{Procesado del modelo 3D}

Posteriormente se añadieron los marcadores y dianas que en la toma de datos se colocaron en el modelo. Esta señalización ayuda al programa a establecer una conexión entre las distintas imágenes haciendo posible una orientación absoluta de estas. En total se ha utilizado un número de dianas entre 4 a 10 en los diferentes retablos. Con todos estos datos se realizó una orientación de las imágenes. Y se obtuvo la nube de puntos por correlación, tras ellos (Fig. 4.a), se realizó la malla triangular (Fig. 4.b), después se ha depurado completando huecos y eliminando errores, mediante el software Geomagic Wrap se ha avanzado en la reparación de la malla tridimensional obtenida, para así eliminar impurezas, oquedades y posibles datos que no corresponden al modelo. A fin de mejorar el modelo, se procede a generar normales. Esto quiere decir que vamos a aumentar la información relativa de cada uno de los puntos para que en el proceso de triangulación de la malla dé como resultado una superficie más exacta. Esta última parte del procesamiento trata la reconstrucción del modelo en 3D. Inicialmente el proceso de reparación de la malla se comienza con el programa Geomagic de forma automática, para pasar después a una forma manual con la utilización del software libre de modelado Blender. Esta fase es una de las que mayor tiempo de trabajo ha generado para conseguir una limpieza total de la malla y la posible reparación de todos los imperfectos que se hayan generado al crear el modelado. Para abordar el objetivo se han establecido dos fases de trabajo en la reconstrucción de la malla generada. Por un lado, se han limpiado todos los elementos externos al retablo como son las paredes laterales para así tener el modelo aislado del entorno. Y, 
posteriormente, se ha homogenizado la malla, evitando así duplicados en la triangulación que provocan errores en la superficie del objeto o acabados que no corresponden.

Finalmente, se genera una única textura en alta calidad para el modelo 3D generado formada por las imágenes y por los mismos parámetros de construcción generados en el proyecto. Por lo que las fases son: obtención y alineado de las diferentes nubes de puntos, tras depurar estos puntos (Fig. 4.a), se realiza la malla triangular que une los puntos y se depuran incoherencias (Fig. 4.b) y, finalmente, se hace el modelo, en el que se proyecta la textura final (Fig. 4.c).

\section{Figura 4}

\section{FASES DEL PROCESADO DE LOS DATOS DE UNA ZONA DEL RETABLO MAYOR DE EL BONILLO, DONDE APARECE EN A) LA NUBE DE PUNTOS OBTENIDA. B) LA MALLA TRIANGULAR GENERADA. C) EL MODELO CON LA TEXTURIZA}

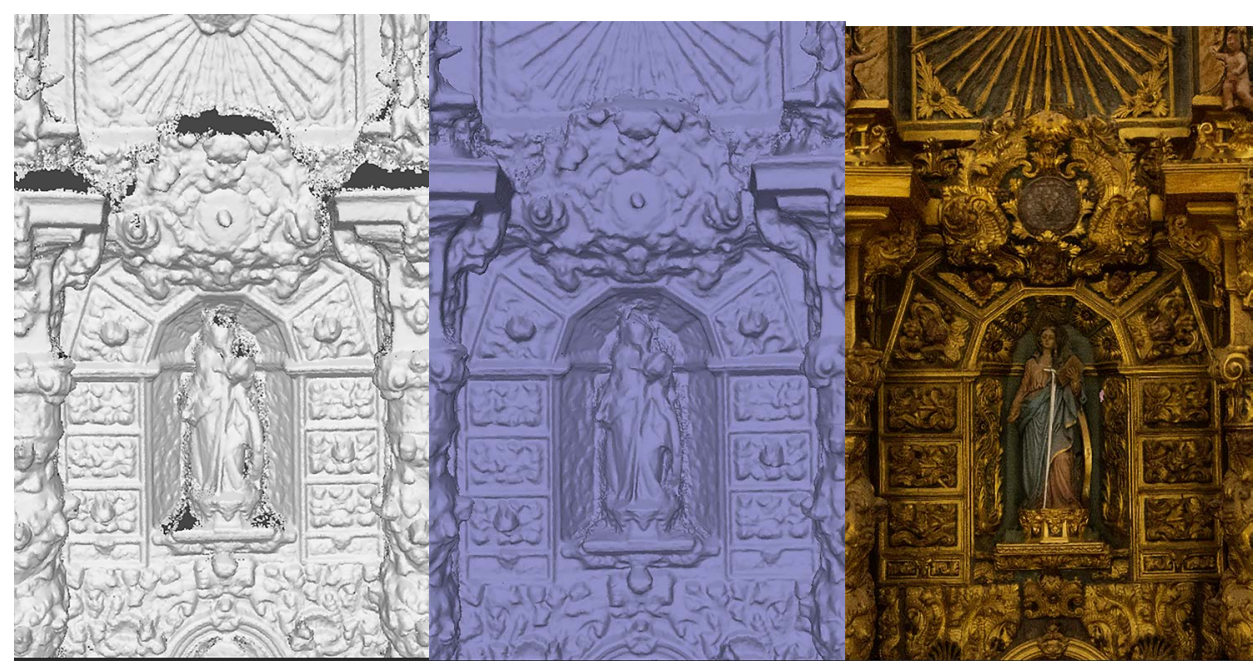

Fuente: Elaboración propia.

\section{RESULTADOS}

Los resultados iniciales garantizan una documentación gráfica tridimensional de los retablos medidos. Además de estos modelos finales y debido a la posibilidad que presenta su divulgación, se somete a la malla obtenida a un proceso de reducción (Fig. 5). Esto es pasar de un modelo sumamente complejo de gran tamaño, a un modelo simplificado y manejable. Este proceso no provoca la pérdida de información, solo hace posible su uso fácilmente. Para ello se procede al diezmado de la malla. Esta acción reduce el número de triangulaciones de la malla para así tener una superficie menos pesada y más manejable. 


\section{Figura 5}

SIMPLIFICACIÓN DE LA MALLA DE LA ESCULTURA DE JESÚS, TITULAR DEL RETABLO DE SANTO DOMINGO DE CARTAGENA, A) MALLA TRIANGULAR, B) MAPA DE NORMALES Y C) MALLA CUADRANGULAR SIMPLIFICADA

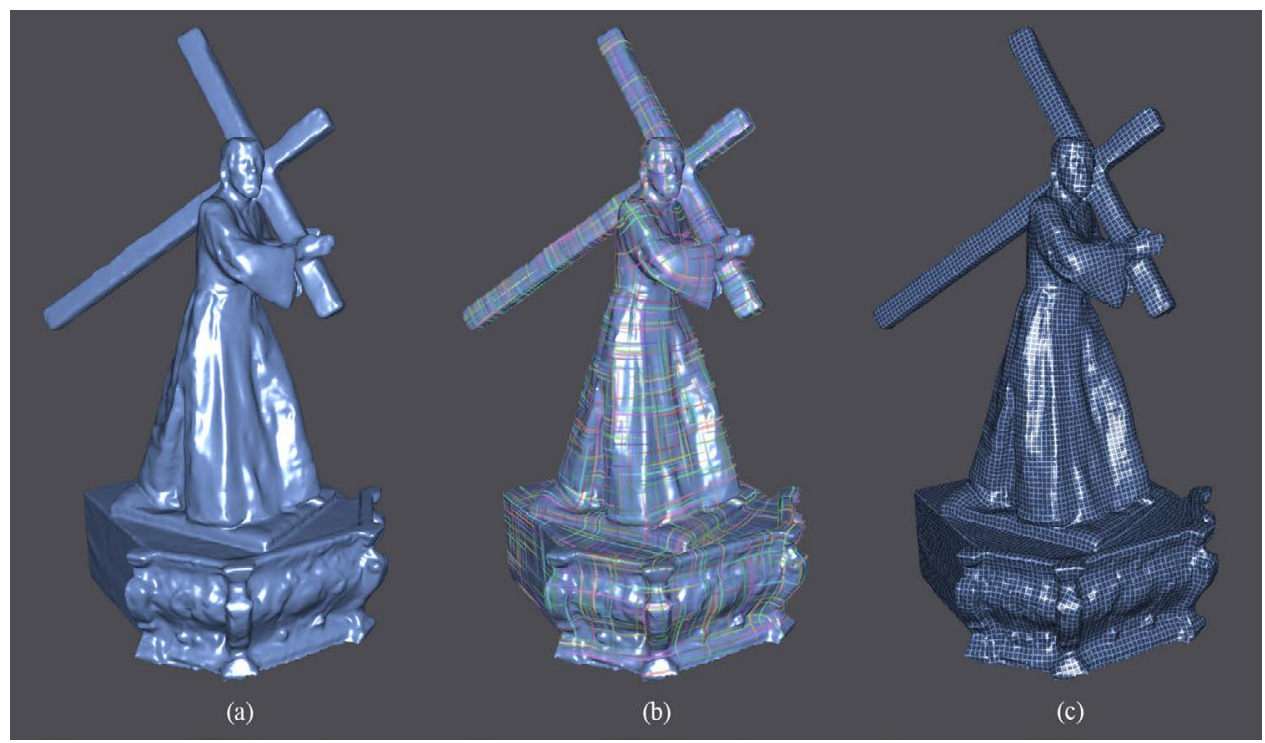

Fuente: Elaboración propia.

Esto permitirá posteriormente situar los modelos en plataformas web sin demasiados problemas. Conseguida la simplificación, finalmente se realiza la técnica de retopology. Este método consta de la transformación de la malla de una estructura triangular a una cuadrangular, siendo esta mucho más adaptable a la hora de texturizar (Fig. 5.c).

\subsection{El modelo tridimensional, una herramienta para el análisis}

El modelo fotogramétrico permite conocer con precisión el objeto de estudio. La lectura conjunta del mismo por parte de profesionales del ámbito de las Humanidades y de la Tecnología está generando nuevas aproximaciones al retablo y redundando en una más adecuada toma de decisiones, con el establecimiento de prioridades y planificación de estrategias de actuación y la promoción de acciones de conservación y difusión. Se dispone de un material con el que efectuar diagnósticos sobre el estado global del retablo, detectando las carencias, corrigiendo desajustes y posibilitando un acercamiento a la pieza, que no se habría logrado, salvo con andamios y con otros medios, que, además de encarecer, interrumpirían el culto y no facilitarían la misma información. Además, convendría elaborar tanto un Plan Nacional de Retablos — dado que hay retablos que no están incluidos en el de Catedrales, ni en el de Abadías, Monasterios y Conventos-, como una Carta de 
Riesgos, continuando en el camino trazado en la Carta de Retablos firmada en Cartagena de Indias el 1 de marzo de 2002 y en el Documento de Retablos 2002 suscrito en Sevilla (recogidos en Bruquetas et al., 2003: 44-48 y González y Descamps (Coords.), 2004: 8-15, respectivamente). Si bien, se está avanzando y ya hay grupos de trabajos centrados en este tema (González-López, 2016) y el proyecto Coremans, enfocado a establecer y unificar criterios para intervenir sobre bienes culturales, también ha centrado su atención en retablos y esculturas en madera policromada (Ceballos, 2017).

Esta documentación es útil como estrategia de conservación preventiva y ante daños y destrucciones por catástrofes naturales y antrópicas y en situaciones de emergencia. En el caso de los retablos, los incendios acontecidos y el peligro que significaba la madera en los templos donde siempre había velas encendidas determinaron, en la segunda mitad del siglo XVIII, la prohibición en el uso de este material. Por otro lado en el Sureste peninsular, las riadas y terremotos han marcado su historia y han afectado a los retablos. El Plan Nacional de Emergencias y Gestión de Riesgos en Patrimonio Cultural de 2015 menciona los estragos del movimiento sísmico de Lorca en Murcia de 2011, que tanto afectó al patrimonio de la Iglesia. También en desamortizaciones y guerras, numerosos retablos desaparecieron.

Con los modelos tridimensionales, se puede analizar separadamente la parte arquitectónica y la escultórica. Así se ha efectuado en el retablo mayor de San Miguel, para evaluar comparativamente el tamaño de las imágenes. Nicolás Salzillo hizo San Miguel, titular de la parroquia, décadas antes que su hijo Francisco realizara los seis arcángeles y la $\mathrm{Fe}$. Ello permitió cotejar las obras y ver que, siendo San Miguel más pequeña -alcanza solo 1,45 metros-, su conformación, su disposición en el retablo y los espejos que envuelven la pieza la resaltan y el espectador apenas percibe la inferioridad de sus dimensiones.

Tras la medición de las esculturas en su posición original, que se aprecia en la figura 6.a, se dispusieron todas ellas en una alineación para comparar su tamaño, viendo claramente que la imagen situada en el centro del retablo, hecha por Nicolás Salzillo, era menor, como se aprecia en la acotación de la figura 6.b.

Generalmente no se pueden mover las imágenes de su emplazamiento, lo que obstaculiza que se puedan tomar correctamente los datos concernientes a la parte posterior de las esculturas. Tampoco la cámara llega a la zona del retablo que ocultan los elementos de bulto redondo. Por tanto, cuando se gira el modelo fotogramétrico y se contempla oblicuamente, las esculturas ofrecen una imagen de su volumetría que no es certera y, además, estas obras impiden la visión del paramento arquitectónico que hay tras ellas y no dejan tomar los datos. Igual sucede tras las columnas y otros soportes y adornos exentos. Así, la parte posterior y no visible de dos columnas salomónicas de El Bonillo está sin trabajar, pero el modelo fotogramétrico no permite observarlo. 


\section{Figura 6}

COMPARACIÓN DE LAS DIMENSIONES DE LAS ESCULTURAS DEL RETABLO MAYOR DE SAN MIGUEL (MURCIA)
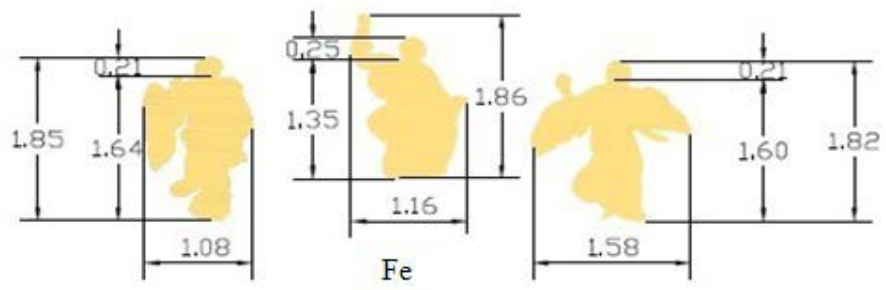

Baraquiel

Jehudiel

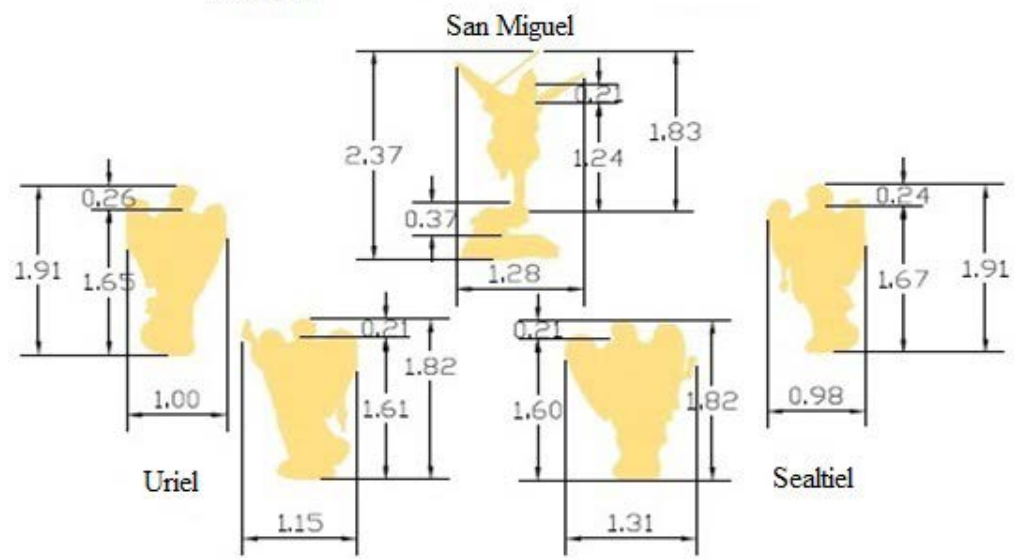

San Rafael

San Gabriel
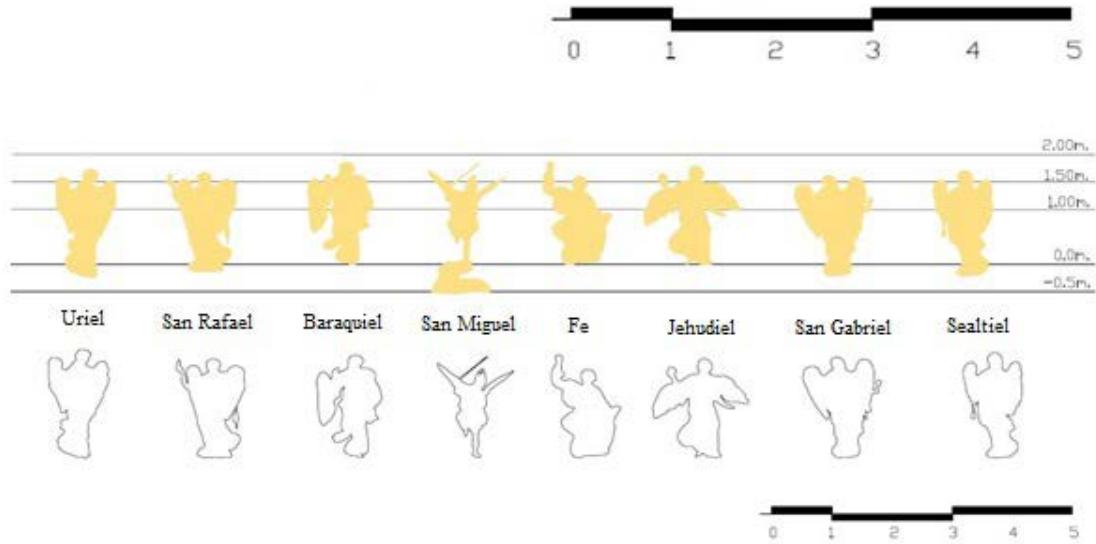

Fuente: Peña-Velasco et al., 2017. 
En consecuencia, es fundamental para una modelización completa de la parte escultórica y arquitectónica tener acceso a la escultura independientemente; es decir, que pueda situarse esta fuera del retablo, para tomar los datos alrededor suyo, a través de diferente metodologías, como se hizo en el retablo de Santo Domingo, donde también se tuvo la oportunidad de fotografiar el camarín con las puertas giratorias abiertas y cerradas. En este caso, se muestra la Dolorosa, pero se efectuó con todas las esculturas del retablo, donde pueden verse los anillos a diferentes alturas en la toma de datos fotogramétricos, tras la orientación relativa (Fig. 7; García-León et al., 2019). Realmente esto es muy complicado de conseguir, pero al mismo tiempo imprescindible si se quiere tener modelada tridimensionalmente la escultura. De otro modo, solo se toman los datos de la parte visible del retablo y el modelado tridimensional de calidad en la parte escultórica es imposible, ni tan siquiera si se tomasen los datos con un dron, ya que el espacio existente entre la hornacina y la parte de atrás de las esculturas es tan pequeño que no puede medirse.

\section{Figura 7}

\section{ESCULTURA DE LA DOLOROSA DEL RETABLO DEL NUESTRO PADRE JESÚS NAZARENO EN SANTO DOMINGO (CARTAGENA). DISPOSICIÓN DE LAS IMÁGENES DE LA TOMA FOTOGRAMÉTRICA DE LA ESCULTURA INDEPENDIENTE}

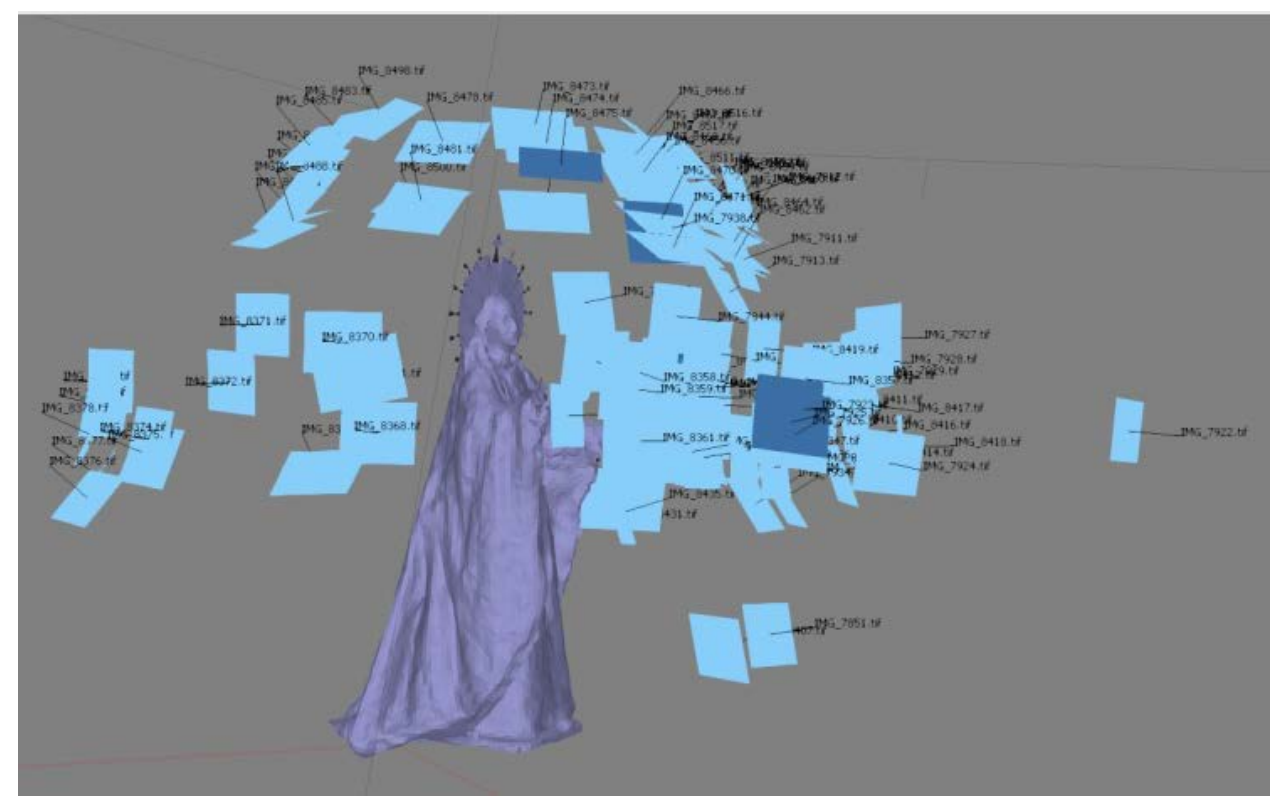

Fuente: García-León et al., 2019.

El modelo permite realizar cortes transversales y longitudinales a distinta altura, logrando así entender su morfología y movimiento de sus estructuras, que no revela sufi- 
cientemente la planta, así se hizo en la capilla marraja cartagenera y en San Miguel de Murcia (García-León et al., 2018; Peña-Velasco et al., 2017). En El Bonillo, se muestra el resultado de las secciones horizontales a diferentes alturas (Fig. 8), que ayudan a entender la posición de los soportes en el retablo, entre otras cuestiones.

A través del análisis de la documentación fotogramétrica se han extraído unas conclusiones generales y otras propias de cada retablo, que permiten efectuar una serie de recomendaciones para abordar este tipo de levantamientos. Así, el modelo obtenido es un universo que permite asignar información asociada, descubrir detalles, estudiar los elementos que componen la estructura y conocer sus dimensiones y proporcionalidad. Cabe plantear, por ejemplo, qué tratados pudieron ser referencia para los órdenes arquitectónicos y para otros aspectos por las especificidades que presentan y por la proporción de los elementos que los componen, pues estas técnicas posibilitan medir con precisión. Además, permiten aproximarse a la obra desde diferentes ángulos de visión y contemplar elementos que no son perceptibles desde la nave del templo, como los atributos relacionados con el arcángel San Miguel, que pasan desapercibidos. Por demás, cabe reponer con exactitud las piezas que faltan en la estructura, efectuando elementos idénticos a partir de los existentes.

\subsection{Un recurso patrimonial y turístico para divulgar}

Como se ha venido repitiendo, los modelos tridimensionales deben ponerse a disposición pública a través de plataformas digitales. Al mover y aproximar la imagen, el usuario puede descubrir detalles que no son perceptibles al ojo y cabe completar con explicaciones y datos que acompañen las imágenes y que contribuyan a la divulgación de este importante legado artístico. Para ello es fundamental que se simplifique la malla, para que ocupe una cantidad de memoria que permita moverla desde estos espacios virtuales. En nuestro caso se ha utilizado la plataforma Sketchfab para publicar dichos modelos; de modo que el retablo de Santo Domingo de Cartagena puede verse en https://skfb.ly/6G7Ou y el retablo de San Miguel de Murcia en https://skfb.ly/6tMrU (Fig. 9). En este último y a modo de ejemplo, se han incluido metadatos, que incorporan información alfanumérica, y el acceso es libre, directo y ágil. Además, cabe georreferenciar y agregar datos relativos a la historia, autoría y singularidad de la obra y detalles como los horarios de visita, que posibiliten que las personas interesadas y los guías turísticos puedan programar satisfactoriamente el acceso al templo y la contemplación de los retablos y que sean de utilidad para incrementar la difusión y sensibilizar en la valoración y la salvaguarda de tan destacados bienes patrimoniales. Además se pueden hacer impresiones 3D de los retablos y de imágenes devocionales y disponerlas en los templos para que puedan ser tocadas por visitantes con discapacidad visual. 
Figura 8

MODELO TRIDIMENSIONAL SIN TEXTURA DEL RETABLO MAYOR DE LA IGLESIA DE SANTA CATALINA, CON SECCIONES HORIZONTALES A DIFERENTES ALTURAS (EL BONILLO)

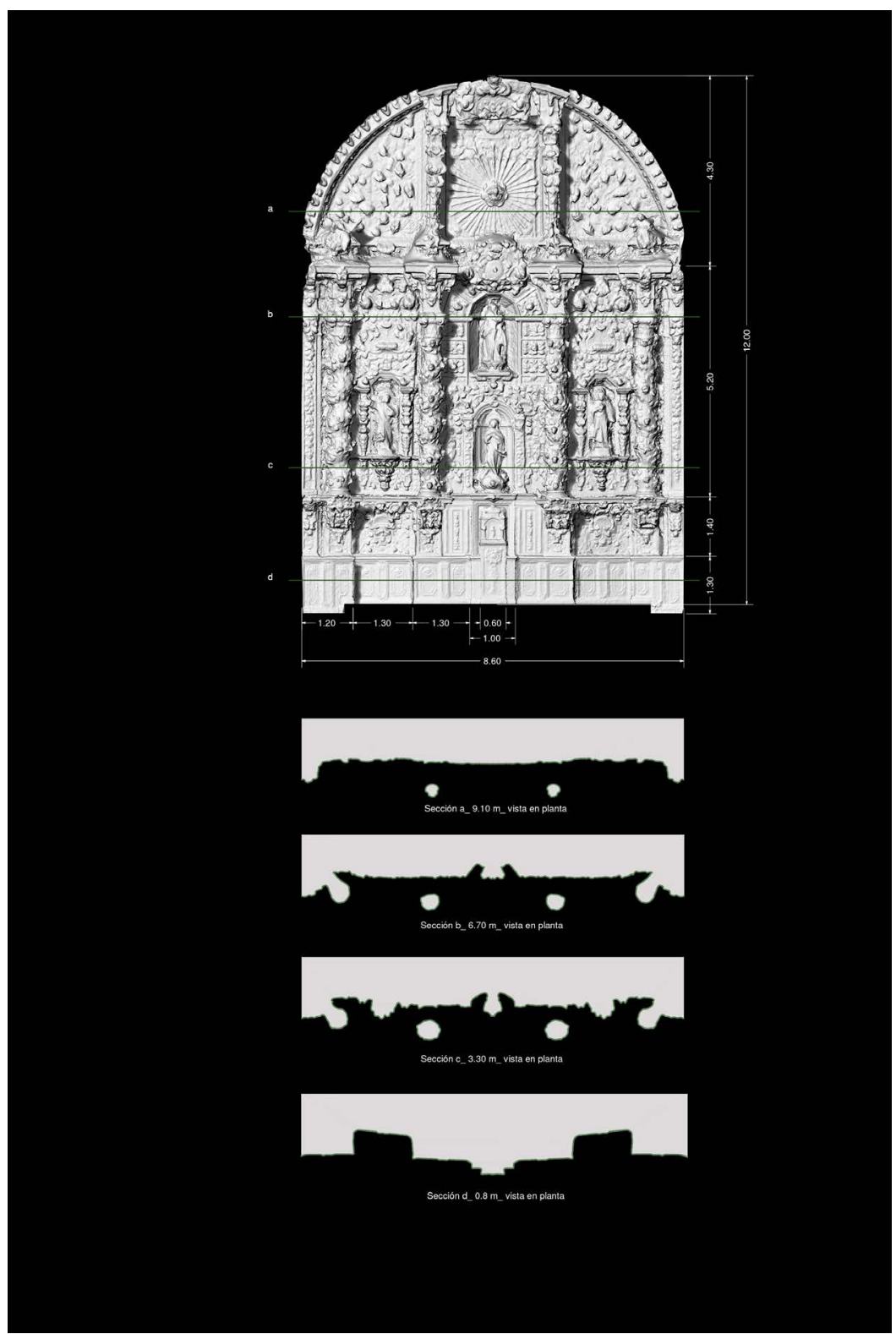

Fuente: Elaboración propia. 


\section{Figura 9}

MODELO TRIDIMENSIONAL DEL RETABLO MAYOR DE LA IGLESIA DE SAN MIGUEL (MURCIA), CON INDICACIÓN DE LAS DIFERENTES PARTES QUE LO COMPONEN https://skfb.ly/6tMrU

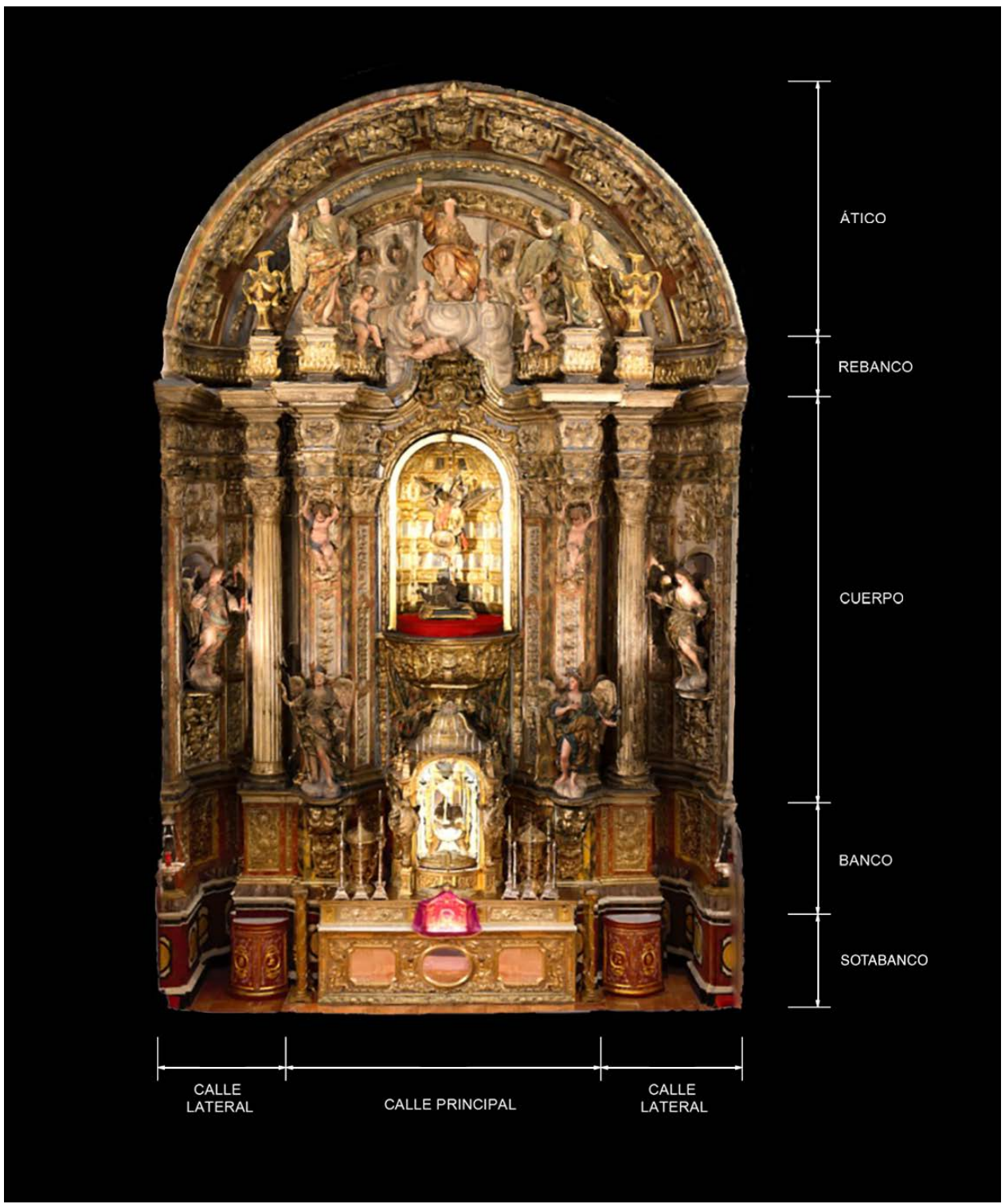

Fuente: Elaboración propia. 
La documentación gráfica generada y cuanto contiene puede ser aprovechada para programar visitas en el contexto del turismo cultural, del turismo religioso y del turismo digital, con la consideración de llegar a un público amplio. Por otro lado y como sucede en otros casos, la difusión en redes potenciaría la consulta de este material. Convendría interconectar los enlaces sobre los retablos con la publicidad sobre las visitas e itinerarios culturales que se programen con motivo del Año Jubilar de Caravaca de la Cruz y con las exposiciones que se han venido efectuando coincidiendo o no con este importante acontecimiento, cuya concesión tuvo lugar en 1998 y comenzó en 2003. Igualmente y dado el considerable número de fiestas de interés turístico internacional, nacional y regional (Domínguez, 2019) y que muchas tienen un origen religioso (romerías, fiestas patronales, procesiones de Semana Santa y del Corpus, etc.), cabría facilitar la información sobre los retablos en la difusión que se haga de tales eventos. Por ende, también cabe hacerlo en la publicidad de La Mañana de Salzillo, declarada Bien de Interés Cultural Inmaterial y con candidatura a Patrimonio Inmaterial de la Humanidad, pues la asistencia es habitualmente multitudinaria a la procesión de los pasos del célebre escultor, cuando salen el Viernes Santo de la ermita de Nuestro Padre Jesús Nazareno y transitan por la ciudad de Murcia.

Por otro lado, en tiempos de pandemia y en otras circunstancias extremas como las que se viven actualmente durante los estados de alarma o en cualquier momento que se desee, un recorrido virtual por los retablos en los diferentes templos o por los más destacados de las ciudades, a la manera de lo que se ha venido programando en museos y exposiciones, ofrecería la posibilidad de disfrutar de obras relevantes sin las limitaciones motivadas por los horarios de apertura, restricciones por el culto, flujo excesivo de visitantes e, incluso, ante posibles situaciones de confinamiento ${ }^{5}$.

\subsection{Gamificación y exposiciones inclusivas}

El modelo obtenido con fotogrametría y láser escáner es muy atractivo para transmitir información, pero también para sensibilizar en educación patrimonial (Ibáñez et al. 2018) y para articular otras acciones y llegar a colectivos vulnerables y con discapacidad. Es posible programar videojuegos para estudiantes de distintas edades, con los modelos como base para la historia, la cultura, el patrimonio y la religión. De este modo, cabe aumentar la motivación, la sensibilización y el interés de los niños por los retablos barrocos (GarcíaLeón et al., 2018). Así se hizo en el estand sobre este tema, que se dispuso en la Semana de la Ciencia y de la Tecnología de la Región de Murcia en noviembre de 2019.

Con el mismo fin divulgativo, se realizó una exposición en marzo de 2019 en la Universidad Politécnica de Cartagena, mostrando las aplicaciones de la Geomática en la documentación del Patrimonio Cultural. Se trató de difundir la importancia de la Fotogrametría

5 La UNESCO ha invitado a compartir experiencias sobre las prácticas del patrimonio inmaterial durante los meses de pandemia, en que se han podido ver alteradas y pospuestas (https://es.unesco.org/news/unescopromueve-cultura-y-patrimonio-durante-crisis-covid-19 y https://es.unesco.org/news/comparte-tu-experienciapatrimonio-cultural-inmaterial-pci [Consulta 30 de octubre de 2020]). Sin duda, sería interesante tomar esta idea y constituir una red por parte de investigadores que trabajan las técnicas geomáticas aplicadas al retablo para ir explicando qué se ha hecho y qué se podría hacer a partir de la documentación gráfica obtenida y comunicar los avances y los problemas originados, más allá de que los resultados a más largo plazo lleguen a publicaciones especializadas. 
y de la medición con láser escáner en la documentación de los retablos. Se intentó acercar el conocimiento de los retablos a la sociedad, considerando siempre el reto de evitar la desigualdad digital (Voronkova, 2020). Se planificaron actividades de Gamificación. Así, partiendo del modelo tridimensional del retablo cartagenero (Fig.10), se articularon juegos educativos que permitían interactuar moviendo las imágenes del Nazareno, la Dolorosa, San Juan, la Verónica y la Magdalena. Se proporcionaron unas claves generales previas, explicando el orden y jerarquía que rige en la colocación de las imágenes y lo sucedido en este retablo pasionario. El usuario elegía y emplazaba como quisiera una de las esculturas en una hornacina y un mensaje argumentaba las razones que aclaraban por qué la opción había sido correcta o incorrecta.

Dicha exposición fue inclusiva y prestó una especial atención a las personas con discapacidad visual, para lo cual se marcaron convenientemente los pasillos por los que discurrir, se prepararon partes sonoras y los textos principales de cada panel estaban en braille. A su vez, la impresión tridimensional de zonas del retablo a través de impresoras 3D permitió tocar modelos a escala, como se ha realizado en museos inclusivos con determinadas esculturas. En este caso, se efectuó una réplica con una impresora 3D a escala, se eligió una zona del retablo, que fue la hornacina de San Juan en la Capilla de Nuestro Padre Jesús Nazareno en Santo Domingo de Cartagena y la escultura de su interior. Las personas con discapacidad visual tuvieron la oportunidad de tocar y entender el retablo, tanto la parte arquitectónica como la escultórica, comprobando la relación entre ambas. Con dicha réplica también se participó en el campus inclusivo realizado en el verano de 2019, conjuntamente con las dos universidades públicas de la Región de Murcia, organizado para que los jóvenes con discapacidad conociesen las universidades y su investigación y encontrasen la motivación para matricularse en ellas.

Además, cabe programar juegos educativos con este conjunto patrimonial o con alguno de sus ejemplares, según la singularidad y las posibilidades que cada obra posea. Por ejemplo, el interés se puede centrar en familiarizar con la especificidad de los términos relacionados con el retablo o con el ritual, bien centrando la atención en los nombres de cada uno de los elementos que componen la estructura dorada de los cuerpos, calles y ático o bien de los enseres que se requieren para el culto. En cuanto a articular algo específico, el retablo mayor de San Miguel de Murcia está repleto de atributos relacionados con el arcángel que se reparten por toda la estructura arquitectónica y que se pierden en una visión global. Si se incentiva al usuario para que interactúe y los busque en el modelo digital, se obtendría un aprendizaje sobre la arquitectura y su ornamentación, sobre los ámbitos idóneos para disponer los motivos, sobre la identificación de los elementos propios del arcángel y sobre lo que es el universo del retablo como receptor de imágenes y de información. 


\section{Figura 10}

MODELO TRIDIMENSIONAL DEL RETABLO DEL NUESTRO PADRE JESÚS NAZARENO EN LA IGLESIA DE SANTO DOMINGO (CARTAGENA) https://skfb.ly/6G7Ou

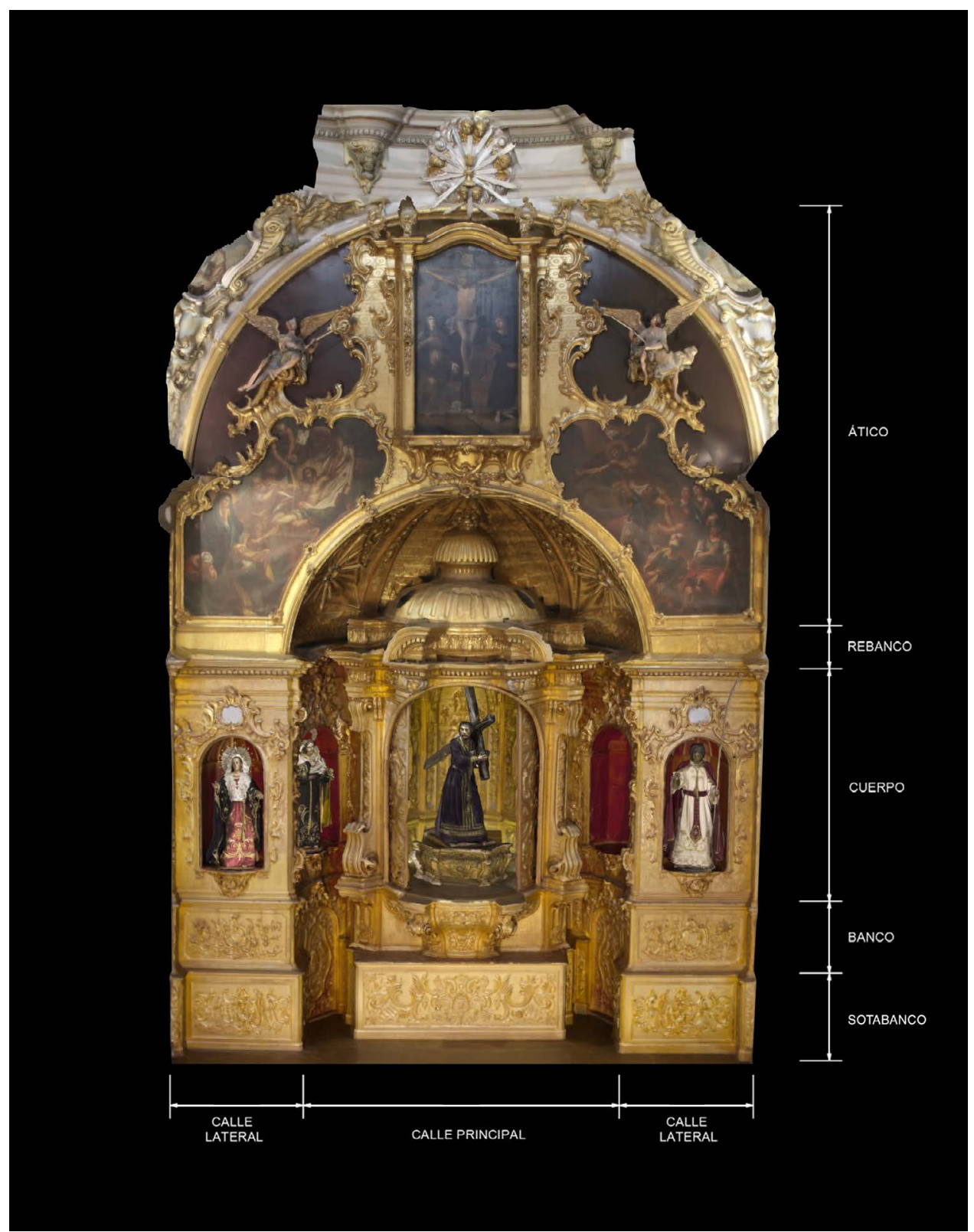

Fuente: Elaboración propia. 


\section{CONSIDERACIONES FINALES}

El uso de la Geomática aplicada a los retablos barrocos y el análisis de los resultados permiten extraer las siguientes consideraciones:

- Los retablos barrocos componen un corpus con particular relevancia cultural, que ha sido estudiado tradicionalmente en su forma y significado. La fotogrametría y el láser escáner están ayudando a conocer mejor este mueble litúrgico y a avanzar en su investigación y difusión, al propio tiempo que una mejor comprensión del bien redunda en un mayor acierto en la fijación de actuaciones para su protección, conservación y divulgación. Aunque la aplicación de tales técnicas al retablo es más tardía que en otros elementos patrimoniales, los avances obtenidos en otros ámbitos como la Arqueología y en bienes muebles e inmuebles están repercutiendo positivamente en el estudio del retablo, en tanto que se puede extrapolar lo aplicado en otras disciplinas y en ciertos objetos artísticos.

- Las expectativas sobre el progreso y posibilidades que ofrecen los modelos tridimensionales son importantes, ya que estos suministran una documentación completa y precisa de este bien patrimonial en cuanto a su forma, medidas, proporción y, en parte, respecto a su estado de conservación. El estudio no acaba con la obtención de tales modelos.Hay que seguir profundizando en las posibilidades de análisis que el material obtenido ofrece y completar con datos que se logren con el estudio de la obra, de los materiales y de las técnicas, así como con la consulta de fuentes primarias sobre su construcción y sobre las intervenciones que haya experimentado la pieza a lo largo del tiempo.

- Se requiere disponer de un mayor número de casos de retablos en los que se hayan aplicado tales técnicas, para aproximarnos con mayor exactitud al tema, encontrándonos en la actualidad en el inicio de un proceso que requiere un esfuerzo prolongado en el tiempo para reunir los datos y estudiarlos. Al menos todo retablo con algún grado de protección legal debería tener información geomática y convendría que se estableciese y normalizase un protocolo para su catalogación y que el acceso a tales datos fuera accesible y gratuito. Como criterio para comenzar a elaborar modelos tridimensionales, se han elegido dos retablos mayores de templos parroquiales y uno de una capilla, ámbitos todos declarados Bien de Interés Cultural con categoría de monumento.

- La constitución de equipos multidisciplinares ha sido esencial para compartir puntos de vista y tomar decisiones que han derivado en acciones, que no siempre son aplicables a otros retablos. En consecuencia, la colaboración e interlocución constantes, cuanto menos entre profesionales con conocimiento de las técnicas geomáticas y del objeto de estudio, favorecen un acercamiento más certero a este patrimonio y contribuyen a aprender más de él y a comprenderlo mejor.

- Los retablos barrocos son objetos muy difíciles de medir por su forma y por su color, generalmente, dorado. Las nuevas tecnologías proporcionan imágenes fieles en lo que registran directamente y el programa recrea otras que permanecen ocultas a la cámara o con dificultades para la toma de datos. Es el caso de la parte posterior de esculturas de bulto y de las columnas, así como de los paramentos que estos elementos tapan. De modo que cuando el usuario gira el modelo tridimensional obtenido y se muestran las tomas laterales y en picada no siempre lo que se ve se corresponde con lo hay. Además, hay que considerar la habilidad del técnico que trabaja con los resultados y que tiene la posibilidad 
de mejorar la realidad, completarla, interpretarla y alterarla. Debe quedar claro cómo es el retablo y qué sale modificado en su imagen fotogramétrica o se modifica durante el proceso de obtención de esta última.

- Cuando se generan modelos tridimensionales, estos pueden materializarse a través de impresoras 3D y favorecer la divulgación de los mismos, acercarlos a personas con discapacidad visual y llegar a otros colectivos vulnerables. Todavía queda mucho por hacer y muchos desafíos por afrontar para facilitar el acceso de estas personas. Además, cabe utilizar las imágenes virtuales en la Gamificación y compaginar entretenimiento y aprendizaje, con propuestas dirigidas a público de diferentes edades. El mundo de lo digital contribuye a conocer, conservar y difundir el patrimonio y hay que planificar, a partir de él, líneas estratégicas para enfrentarse a este bien con significación social.

- Convendría tener documentación precisa tridimensional de todos los retablos, comenzando por los situados en los presbiterios como lugares hegemónicos y los que tienen la categoría de Bien de Interés Cultural. Más allá de la utilidad que esta documentación fotogramétrica ostenta para la investigación y conservación y ante posibles riesgos de catástrofes y otras contingencias, estas obras forman parte de la identidad y del acervo cultural de las gentes y hay que aprovechar las posibilidades y retos que las TIC ofrecen. Poner en la web estas imágenes tridimensionales con acceso libre contribuiría a su valoración, divulgación y concienciación sobre la importancia de su salvaguarda.

- La imagen virtual del retablo no manifiesta todos sus valores como patrimonio material e inmaterial, ni los cambios en su percepción sensorial a diferentes horas del día, pese a que se logre perfeccionar la técnica y adaptarla a lo que este bien requiere y que se agregue sonoridad y otro material posible que aproxime a lo que implica su puesta en escena. La dimensión magnificente y sensorial, con toda la variación y sutilezas que el objeto proporciona, la adquiere durante el ceremonial. Nada sustituye el disfrute y el componente emotivo de la contemplación directa en ese espacio de emociones que es el templo, lugar para el que fueron proyectadas estas singulares obras de arte, que son síntesis de la interconexión que tuvieron maestros de diferentes profesiones en el pasado y ejemplo para que el camino de colaboración entre disciplinas se prolongue y mantenga en el presente y el futuro.

- Disponer de un material de esta categoría en plataformas de acceso gratuito coadyuvaría a reforzar el vínculo del bien con la sociedad que lo disfruta y, muy especialmente, con aquella que se identifica con él, porque forma parte de su idiosincrasia. Es el caso de Murcia con Francisco Salzillo - y el retablo principal de San Miguel alberga obras tempranas del escultor-; de Cartagena y la Cofradía Marraja - y el retablo de Nuestro Padre Jesús Nazareno es un bien patrimonial significativo y querido en la ciudad - y de El Bonillo y su parroquia - con lo que implicaba e implica el retablo mayor del templo como sitial de las imágenes devocionales en las antaño pequeñas villas situadas en los territorios de la Monarquía Hispánica en el Antiguo Régimen-.

Declaración responsable: Las autoras declaran que no existe ningún conflicto de interés en relación a la publicación de este artículo. Las tareas se han distribuido del modo siguiente. El diseño general del artículo ha sido obra de Concepción de la Peña Velasco 
y Josefina García León, así como el apartado de discusión de resultados. Las fuentes de información históricas y administrativas y las representaciones cartográficas han recaído en Concepción de la Peña Velasco, Josefina García León y María de los Ángeles Riquelme Gómez. La aplicación metodológica, decisiones al respecto, redacción del texto y revisión bibliográfica y legislativa ha sido responsabilidad de las dos primeras autoras.

\section{BIBLIOGRAFÍA}

BRUQUETAS, R., CARRASCÓN, A. y GÓMEZ ESPINOSA, T. (2003): «Los retablos. Conocer y conservar», Bienes culturales: Revista del Instituto del Patrimonio Histórico Español, ${ }^{\circ}$ 2, pp. 13-48.

CANTOS MARTÍNEZ, O., LODEIRO PÉREZ, J.M. y LAGUNA RODRÍGUEZ, F.J. (2009): «La fotogrametría como apoyo gráfico en la restauración de retablos escultóricos en madera policromada», Patrimonio Cultural de España, ${ }^{\circ}$ 1, pp. 237-251.

CEBALLOS ENRÍQUEZ, L. (Coord.) (2017): Proyecto COREMANS: Criterios de intervención en retablos y escultura policromada. Madrid, Ministerio de Educación, Cultura y Deporte.

CIPRIANI, L., FANTINI, F. y BERTACCHI, S. (2015): «El color en las piedras y en los mosaicos de Rávena: nuevas imágenes de los monumentos antiguos a través de la fotogrametría no convencional de última generación», Expresión Gráfica Arquitectónica, $\mathrm{n}^{\circ} 26$ (20), pp. 190-201.

DÁVILA, M. (2014): «Restitución fotogramétrica de retablos. Naves laterales de la Iglesia de San Jacinto, Caracas», Blucher Design Proceedings, vol. 1 (8), pp. 158-161.

DOMÍNGUEZ POSADA, C. (2019): Las fiestas de la Región de Murcia como Patrimonio Inmaterial de Interés Turístico. Trabajo Fin de Máster, Universidad de Murcia.

GAIANI, M., BENEDETTI, B. y APOLLONIO, F. I. (2011): «Teorie per rappresentare e comunicare i siti archeologici attraverso modelli critici», SCIRES-IT-SCientific REsearch and Information Technology, vol. 1 (2), pp. 33-70.

GAIANI, M., APOLLONIO, F. I. y FANTINI, F. (2020): «Una metodología inteligente para la digitalización de colecciones museísticas», EGA. Expresión Gráfica Arquitectónica, vol. 25 (38), pp. 170-181.

GALLEGO GÓMEZ, J. (2017): «El derecho de visita pública en los Bienes de Interés Cultural: Análisis jurisprudencial», erph_Revista electrónica de Patrimonio histórico, $\mathrm{n}^{\circ} 21$, pp. 6-38.

GARCÍA-LEÓN, J., SÁNCHEZ-ALLEGUE, P., PEÑA-VELASCO, C., CIPRIANI, L. y FANTINI, F. (2018): «Interactive Dissemination of the 3D Model of a Baroque Altarpiece: A Pipeline from Digital Survey to Game Engines», SCientific RESearch and Information Technology Scires-it, vol. 8 (2), pp. 59-76.

GARCÍA-SAÚCO BELÉNDEZ, L.G. (2002): «El retablo mayor de Santa Catalina de El Bonillo», en Santamaría, A., García-Saúco, L. G. y Sánchez Ferrer, J. (Eds.). II Congreso de Historia de Albacete. Edad Moderna. Albacete, Instituto de Estudios Albacetenses, III, pp. 291-293. 
GONZÁLEZ-ALONSO MARTÍNEZ, E. (1997): Tratado del dorado, plateado y su policromía. Tecnología, conservación y restauración. Valencia, Universidad Politécnica de Valencia.

GONZÁLEZ-LÓPEZ, M.J. (2016): «Los Retablos. Problemática y pautas de actuación», en Roig Picazo, P. y Lacambra, V.M. (Coords.) Actas de la I ${ }^{a}$ Jornada sobre Retablos. Gea de Albarracín, Albarracín, Área de Cultura, pp. 13-62.

GONZÁLEZ-LÓPEZ, M. J. y DESCAMPS, F. (Coords.) (2004): Taller sobre metodología para la conservación de retablos de madera policromada. El Documento de Retablos 2002. Sevilla, Junta de Andalucía y The Getty Conservation Institute.

HERRERA MALDONADO, E. y ZAPATA ALARCÓN, J. (2002): «Arquitectura y ornato en la Iglesia Parroquial de Santa Catalina en El Bonillo en el siglo XVIII», en Santamaría, A., García-Saúco, L.G. y Sánchez Ferrer, J. (Eds.) II Congreso de Historia de Albacete. Edad Moderna. Albacete, Instituto de Estudios Albacetenses, III, 295-325.

IBÁÑEZ-ETXEBERRIA, A., FONTAL MERILLAS, O. y RIVERO GRACIA, P. (2018): «Educación Patrimonial y TIC en España: marco normativo, variables estructurales y programas frecuentes», Arbor, vol. 194 (788), pp. 1-17.

JIMÉNEZ ALCARAZ, J.F., RODRÍGUEZ, G.F. y MARIS MASSA, S. (Coords.) (2020): Humanidades digitales y videojuegos. Murcia, Editum.

LOWE, A., MITCHELL, E., BÉLIARD, N. et al. (2020): The Aura in the Age of Digital Materiality: Rethinking Preservation in the shadow of an uncertain future. Milán, Silvana Editoriale.

MARTÍN GONZÁLEZ, J. J. (1993): El retablo barroco en España. Madrid, Alpuerto.

MELENDRERAS RUIZ, R., MARÍN TORRES, M.T. y SÁNCHEZ ALLEGUE, P. (2020), «Flujo de trabajo para la digitalización 3D mediante fotogrametría de las tallas de madera policromada del Santísimo Cristo de la Sangre y su ángel», erph_Revista Electrónica de Patrimonio Histórico, $\mathrm{n}^{\circ}$ 27, pp. 62-93.

MONTOJO MONTOJO, V. y MESTRE DE SAN JUAN PELEGRÍN, F. (2009): «La Cofradía de Nuestro Padre Jesús Nazareno de Cartagena. Contexto histórico y devenir de la cofradía en la Edad Moderna», en Negroles Sánchez, J. (Ed.) Actas del Tercer Congreso Nacional Advocación de Jesús Nazareno. Cartagena, Cofradía Marrajos, pp. 235-244.

PEÑA-VELASCO, C., GARCÍA-LEÓN, J. y SÁNCHEZ-ALLEGUE, P. (2017): «Documentación, conservación y difusión de un retablo a través de la Geomática: el retablo barroco de la Iglesia de San Miguel en Murcia», erph_Revista electrónica de Patrimonio Histórico, $\mathrm{n}^{\circ}$ 21, pp. 67-90.

REMONDINO, F. (2011): «Heritage Recording and 3D Modeling with Photogrammetry and 3D Scanning», Remote Sensing, vol. 3 (6), pp. 1.104-1.138.

RODRÍGUEZ G. DE CEBALLOS, A. (1992): «Espacio sacro teatralizado: el influyo de las técnicas escénicas en el retablo barroco», en En torno al teatro del Siglo de Oro. Almería, Instituto de Estudios Almerienses, pp. 137-151.

ROMERO, J. (2020): «Estudio formal, simbólico y estilístico de la Iglesia de Zaruma a través de su levantamiento fotogramétrico y relevamiento», Estoa. Revista de la Facultad de Arquitectura y Urbanismo de la Universidad de Cuenca, vol. 9 (17), pp. 61-85. 
SÁNCHEZ MORENO, J. (1945): Vida y obra de Francisco Salzillo. Una escuela de escultura en Murcia. Murcia, Nogués.

YASTIKLI, N. (2007): «Documentation of cultural heritage using digital photogrammetry and laser scanning», Journal Cultural Heritage, vol. 8 (4), pp. $432-427$.

VORONKOVA, L.P. (2020): «Transformación digital del turismo en América Latina», Iberoamérica, $\mathrm{n}^{\circ} 2$, pp. 91-108. 